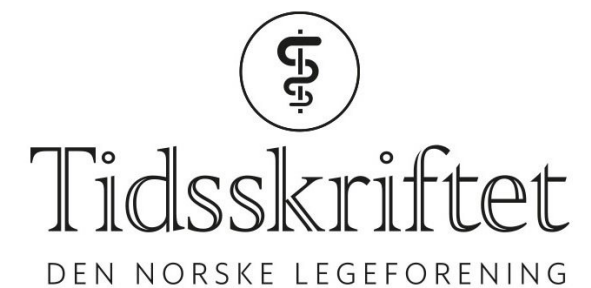

DEN NORSKE LEGEFORENING

\title{
Livsglede i et kort barneliv
}

PERSONLIGE OPPLEVELSER

ANONYM

Forfatteren ønsker å være anonym, men vedkommendes identitet er kjent for redaksjonen.

Vår datters høyeste ønske var å få leve som før - de dagene hun hadde igjen.

Datteren vår på ti år strener inn hovedporten til Rikshospitalet. Vi foreldre løper etter den bestemte ungen. Hun er blant de 4-5 barna som årlig får diagnosen diffuse ponsgliomer (DIPG) i Norge, en dødelig hjernesvulst. Jenta vår forespeiles en fremtid på 9-24 måneder. Et tidsvindu hvor alle familiemedlemmene, alle elever i klassen og i dansegruppa er til stede og hvor livet skal leves. Håpet om feil diagnose varer helt til hun dør hjemme, 13 måneder etter diagnosen. Hva lærte vi i løpet av dette året i møtet med ulike leger, sykepleiere, ambulansepersonale, fysioterapeuter, ergoterapeuter, sosionomer, psykologer, farmasøyter, hjelpemiddelteknikere, musikkpedagoger og lærere på sykehus?

\section{Hva er livskvalitet?}

Da DIPG-diagnosen ble overbrakt oss foreldre, opplevde vi en følelse av lammelse og at bare øyelokkene morset SOS-meldinger til omverdenen. Men handlekraften kom raskt tilbake. Vi bestemte oss for å gi minstejenta et godt liv, de dagene som var igjen. Livskvalitet er definert som livsglede og livsnytelse og at man finner mening i det man gjør (1). Hva betyr det for en tiåring? Venner, skole, fritidsaktiviteter, søsken og lek i gata, til og med lekser, representerer livskvalitet når man er ti år. Vår datters høyeste ønske var å ikke være på sykehuset, men leve hjemme. Det ønsket ville vi etterkomme. Vi skulle være sammen som familie, bo hjemme og fremme livskvalitet og livsglede.

Dette var vi enige om, men likevel sto vi igjen med mange spørsmål. Hvordan ivaretar man livsgleden til et dødssykt barn i en familie med flere barn? Når skal man frata barnet håpet om bedre helse eller håpet om et langt liv? Økes livskvaliteten ved å reise til utlandet for å søke behandling? Hva da med søsken? Ønsket vi å frata dem muligheten til å være nær i livets siste fase? Når vil livets siste fase komme? Og hvor ærlig skal man være med nær familie og venner om sykdom og prognose? Hva med skolen, venner og lærere? Hvor mye kreft og død skal et nærmiljø tåle?

\section{For mange prøver?}

I helsevesenet er det fokus på færrest mulig liggedøgn, godt pasientforløp, prioriteringsveiledere, kommunikasjon med pasient og pårørende, forskning og faglige retningslinjer. Men hva med livskvalitet og livsglede midt i alt dette? Et godt vurdert MRbilde, vil det gi et bedre liv? Medisinsk sett ja, fordi det gir behandlingsrom, men kanskje ikke menneskelig sett. Hvordan skal man tenke? Jeg mener at man som behandler bør gå 
gjennom alle prosedyrer og faktisk spørre seg selv: Er dette nødvendig? Vi opplevde at mange av blodprøvene, legeundersøkelsene og sykehusoppholdene kunne vært unngått. Som foreldre til et sykt barn måtte vi insistere på at ting kunne skje på lokalsykehuset. Det føltes meningsløst å kjøre i 3-4 timer for å ta en blodprøve, gi intravenøs medisin eller skylle et venekateter når det samme kunne gjøres lokalt med en kjøretid på 20 minutter.

Må alle dødssyke barn ha en løvemamma og løvepappa for å få være hjemme så lenge de selv $\emptyset$ nsker det?

Barnet må få bruke energien sin på det som gir glede (2). Møter og samtaler med helsepersonell for å fremme vårt syn på hva vi ville at jenta vår skulle oppleve av helsevesenet, tok mye energi. Vi jobbet hardt for å unngå at jenta vår brukte krefter på unødige treff med helsepersonell. For å få bedre klarhet i behandlingsalternativer kontaktet vi onkologer i USA, som gav gode råd, da vi opplevde at valg av behandling var mye opp til oss selv å avgjøre. Det var ikke en god følelse. Vår trygghet ble best ivaretatt av lokale leger, fastlege og palliativ ansvarlig lege i vår kommune samt barneleger ved nærmeste barneavdeling.

Spørsmålet vi har stilt oss selv er: Blir andre barns livskvalitet og ønske om å være i nærmiljøet ivaretatt av helsepersonell? Tør man stole på at lokal kompetanse kan gjøre hverdagen god for dødssyke barn og deres familier? Får alle foreldre følgende beskjed fra palliativ lokal lege tidlig i sykdomsforløpet: «Vi kan hjemmebehandling i vår kommune vær trygg på det, om det blir aktuelt!» Må alle dødssyke barn ha en løvemamma og løvepappa for å få være hjemme så lenge de selv ønsker det, og som passer på at alle sykehusopphold og prøvetakinger forløper enklest mulig?

\section{Den siste tiden}

Datteren vår fikk få sykehusdøgn. Hennes venner fikk komme på besøk til henne hjemme, selv når alle funksjoner var sterkt reduserte. Familie, venner og søsken fikk erfare godt kommunalt teamarbeid, trygge lokale leger og hjelpemidler som var tilpasset situasjonen. Dette bidro til at vi fikk oppfylt hennes ønske om å være hjemme helt til siste åndedrag.

Barns glede og latter er den beste medisin for slitne foreldre. Vi blir slitne når vi møter helsepersonell som ikke ser løsninger i samarbeid, men kun vanskeligheter. Vi brøler høyt og lenge, i sorg, savn og oppgitthet over at man ikke ser hele bildet, men fester kun blikket på en brikke; diagnosen. Løft blikket, se helheten, kjemp for god og lokal helsetjeneste til barnas beste! Inntil fremtidens forskning gir barn med diagnosen diffuse ponsgliomer tittelen «kreftoverlever», må vi ha fokus på samarbeid for å fremme livsglede og livsnytelse.

\section{LITTERATUR:}

1. Mandrell BN, Baker J, Levine D et al. Children with minimal chance for cure: parent proxy of the child's health-related quality of life and the effect on parental physical and mental health during treatment. J Neurooncol 2016; 129:373-81. [PubMed][CrossRef]

2. Sison J, Tran H, Margol A et al. Palliative Care Options for a Young Adult Patient with a Diffuse Intrinsic Pontine Glioma. Cureus 2017; 9: e158o. [PubMed][CrossRef]

Publisert: 7. oktober 2019. Tidsskr Nor Legeforen. DOI: 10.4045/tidsskr.19.0263

Mottatt 28.3.2019, første revisjon innsendt 3.6.2019, godkjent 27.6.2019.

(C) Tidsskrift for Den norske legeforening 2020. Lastet ned fra tidsskriftet.no 